\title{
PENGARUH PENDIDIKAN KESEHATAN TENTANG DETEKSI DINI KANKER SERVIKS TERHADAP MOTIVASI DALAM MELAKUKAN PEMERIKSAAN IVA DI PUSKESMAS PAL III PONTIANAK TAHUN 2019
}

\author{
Akademi Kebidanan Panca Bhakti Pontianak \\ Email korespondensi:akbidpbpontianak@gmail.com
}

\begin{abstract}
Abstrak
Jumlah WUS yang melakukan pemeriksaan deteksi dini kanker serviks di Kalimantan Barat pada tahun 2017 sebanyak 14.450 perempuan atau 21,56\% dari target perempuan usia 30-50 tahun diantaranya sebanyak 67.018 jiwa, yang terdeteksi IVA positif atau curiga kanker serviks sebanyak 563 jiwa atau 3,90\% hal ini menunjukan masih kurangnya partisipasi wanita terhadap deteksi dini kanker serviks. Tujuan penelitian ini untuk mengetahui pengaruh penyuluhan kesehatan tentang deteksi dini kanker serviks terhadap motivasi wus dalam melakukan pemeriksaan IVA DI Wilayah Kerja Puskesmas Pal Ill Pontianak Tahun 2019. Desain penelitian yaitu quasi experimental design dengan rancangan one group pretest design. Populasi penelitian ini sebanyak 1.683 WUS sampel sebanyak 44 orang di tambah $10 \%$ menjadi 48 responden. Teknik sampling menggunakan Purposive Sampling. Teknik analisis yang di gunakan adalah Uji Wilcoxon Mart Pairs Test. Hasil penelitian ini ialah ada pengaruh penyuluhan kesehatan tentang deteksi dini kanker serviks terhadap motivasi WUS dalam melakukan pemeriksaan iva di wilyah kerja Puskesmas Pal 111 Pontianak tahun 2019. Berdasarkan hasil pengumpulan data yang diperoleh di Puskemas Pal III Tahun 2019 ada pengaruh penyuluhan kesehatan terhadap motivasi WUS maka perlu adanya peningkatan pelayanan kesehatan, terutama pemberian penyuluhan kesehatan tentang deteksi dini kanker serviks dengan metode IVA Oleh karena itu diharapkan kepada petugas kesehatan untuk terus memberikan informasi tentang deteksi dini kanker serviks dengan metode IVA.
\end{abstract}

Kata kunci: Penyuluhan Kesehatan, Deteksi Dini, Kanker Serviks, Metode IVA

\begin{abstract}
The number of fertile women who have early detection of cervical cancer in West Kalimantan in 2017 is 14.450 women or $21.56 \%$ of the target women aged 30-50 years including 67.018 people, detected by IVA positive or suspicious of cervical cancer of 563 people or 3, $90 \%$ of this shows the lack of women's participation in early detection of cervical cancer. The purpose of this study was to determine the effect of health education on early detection of cervical cancer on fertile women motivation in conducting IVA examinations in Pontianak Pal III Health Center in 2019. The study design was a quasi-experimental design with the design of one pretest group. The population of this study was 1,683 WUS samples from 44 people plus $10 \%$ to 48 respondents. The sampling technique uses purposive sampling. The analysis technique used is the Wilcoxon Mart Pairs Test. The results of this study are that there is an effect of health education on early detection of cervical cancer on fertile women motivation in conducting IVA examinations in the working area of the Pontianak Pal III Health Center in 2019. Based on the results of data collection obtained at Pal III Health Center in 2019 there is an influence of health education on fertile women motivation needs to improve health services, especially the provision of health education about early detection of cervical cancer by the IVA method. It is therefore expected that health workers continue to provide information about early detection of cervical cancer by the IVA method
\end{abstract}

Keywords: Health Counseling, Early Detection, Cervical Cancer, IVA Method

\section{Pendahuluan}

Kanker serviks menjadi suatu adalah tumor ganas yang tumbuh di dalam permasalahan kesehatan wanita yang perlu leher rahim atau serviks yaitu kanker yang mendapat perhatian serius. Kanker serviks terjadi pada serviks uterus, suatu daerah pada

\footnotetext{
${ }^{1}$ Dosen Akademi Kebidanan Panca Bhakti Pontianak

${ }^{2}$ Dosen Akademi Kebidanan Panca Bhakti Pontianak

${ }^{3}$ Mahasiswa Akademi Kebidanan Panca Bhakti Pontianak
} 
organ reproduksi wanita yang merupakan pintu masuk ke rahim yang terletak antara uterus dengan liang sanggama (vagina) (Zuliyanti, 2015).

\section{World Health Organization (WHO)} pada tahun 2012 menyatakan bahwa kanker merupakan penyakit tidak menular yang mengakibatkan kematian terbanyak didunia. Dalam hal ini kanker menempati urutan nomor 2 penyakit mematikan setelah penyakit jantung dan pembuluh darah. Setiap tahunnya terdapat 12 juta penderita kanker serviks dan 7,6 juta jiwa diantaranya meninggal dunia (Depkes, 2012).

Globacan yang merupakan salah satu proyek dari International Agency For Reasearch on Cancer (IARC) yang juga melaporkan pada tahun 2008, bahwa kanker serviks menempati urutan kedua setelah kanker payudara dengan kejadian rata-rata 15 per 100.000 wanita, dan sebesar $7,8 \%$ per tahun meninggal dunia akibat kanker serviks pada seluruh wanita didunia ( Ferlay, 2012).

Menurut data informasi kesehatan (2015), Provinsi yang mengalami kanker tertinggi di indonesia adalah Jawa Tengah sebesar 20.548 jiwa pada tahun 2015, meskipun sudah mengalami penurunan sejak tahun 2013 yaitu sebesar 68.638 orang, akan tetapi angka tersebut masih menjadi perhatian khusus. Oleh karena itu, penting dilakukan pemeriksaan rutin secara berkala sebagai upaya pencegahan dan deteksi dini kanker (Data Informasi Kesehatan, 2015).

Insiden kanker serviks sebenarnya dapat ditekan dengan melakukan upaya pencegahan primer seperti meningkatkan atau intensifikasi kegiatan penyuluhan kepada masyarakat untuk menjalankan pola hidup sehat, menghindari faktor risiko terkena kanker, melakukan imunisasi dengan vaksin Human Papilloma Virus (HPV) dan diikuti dengan deteksi dini kanker serviks tersebut melalui pemeriksaan pap smear atau IVA (inspeksi visual dengan menggunakan asam asetat). Saat ini cakupan "screening" deteksi dini kanker serviks di Indonesia melalui pap smear dan IVA masih sangat rendah padahal cakupan "Screening" yang efektif dalam menurunkan angka kesakitan dan angka kematian karena kanker serviks adalah $85 \%$ (Septadina, 2015).

Jumlah wanita usia subur yang melakukan deteksi dini kanker serviks di Kalimantan Barat pada tahun 2017 sebanyak 14.450 perempuan atau $21,56 \%$ dari target perempuan usia 30-50 tahun, diantaranya sebanyak 67.018 jiwa, yang terdeksi IVA positif atau curiga kanker leher rahim sebanyak 563 jiwa atau 3,90\% hal ini menunjukkan masih sangat kurangnya partisipasi wanita terhadap deteksi dini kanker serviks (Profil Kesehatan Provinsi Kalimantan Barat, 2017).

Berdasarkan Profil Dinas Kesehatan Kota Pontianak pada tahun 2018 dari empat Puskesmas Karya mulya, Jendral Urip, Alianyang, Puskesmas Pal 111 yang berada di pontianak kota yang memiliki jumlah sasaran wanita usia subur tertinggi untuk melakukan pemeriksaan IVA adalah Puskesmas Pal III yaitu sebanyak 6,761 jiwa. Wanita usia subur 
yang melakukan pemeriksaan IVA di Puskesmas Pal III sebanyak 1,3\% atau 89 jiwa akan tetapi, target pemeriksaan IVA di Puskesmas PAL III belum mencapai cakupan yang telah ditentukan yaitu 7,5\% atau 507 jiwa.

Keberhasilan pemeriksaan IVA ini dapat dipengaruhi oleh motivasi wanita usia subur dalam melakukan pemeriksaan IVA. Motivasi merupakan bagian penting dalam upaya penanggulangan penyakit kanker serviks. Berdasarkan penelitian dibeberapa negara masih menunjukkan kurangnya motivasi wanita untuk mengikuti program skrining. Rendahnya motivasi wanita usia subur dalam melakukan pendeteksian kanker serviks secara dini disebabkan kurangnya informasi oleh pusat pelayanan dan masyarakat yang kurang terpapar informasi tentang deteksi dini kanker serviks sehingga kemauan untuk peduli akan kesehatan kurang dan keterjangkauan sarana yang sangat jauh (Rachmadaniar, 2013).

Penelitian sebelumnya yang dilakukan oleh Liska tahun 2016 berjudul gambaran motivasi wanita usia subur untuk melakukan test IVA di Desa Canggal Kecamatan Candiroto Kabupaten Temanggung menunjukan hasil penelitian bahwa motivasi wanita usia subur untuk melakukan test IVA dalam kategori kurang sejumlah 49 orang (57\%) lebih besar dibanding dengan kategori baik yaitu sejumlah 37 orang (43\%).

Hal-hal yang mempengaruhi motivasi adalah faktor kepribadian, intelegensi, ciri-ciri fisik, kebiasaan, kesadaran, minat, bakat, kemauan, antusiasme, lingkungan fisik, lingkungan sosial, regulasi, dan lain-lain. Faktor lingkungan mempengaruhi motivasi karena semua kondisi yang berasal dari internal dan eksternal yang mempengaruhi dan berakibat terhadap perkembangan dan prilaku seseorang dan kelompok, Sedangkan yang termasuk faktor intrinsik yang mempengaruhi motivasi yaitu pengetahuan, pendidikan, pekerjaan (Lestari, 2015).

Oleh sebab itu untuk meningkatkan motivasi ibu perlu dilakukan sosialisasi tentang pentingnya IVA, pencegahan kanker serviks dan sumber informasi yang memadai sehingga cakupan pemeriksaan IVA dapat meningkat dan angka kejadian kanker serviks dapat dicegah seoptimal mungkin sebab deteksi dini merupakan skrining yang lebih efektif (Nurus, 2010).

Berdasarkan hasil uji diagnostik, pemeriksaan IVA memiliki sensitifitas $84 \%$, spesifisitas $89 \%$, nilai duga positif $87 \%$, dan nilai duga negatif $88 \%$, sedangkan pemeriksaan pap smear memiliki sensitifitas $55 \%$, spesifisitas $90 \%$, nilai duga positif $84 \%$, dan nilai duga negatif $69 \%$, sehingga dari hasil tersebut dapat disimpulkan bahwa pemeriksaan IVA lebih cepat memberikan hasil sensitivitas yang tinggi. Metode IVA ini merupakan sebuah metode skrining yang praktis dan murah, sehingga diharapkan temuan kanker serviks dapat diketahui secara dini (Rasjidi, 2012).

Berdasarkan hasil studi pendahuluan yang peneliti lakukan pada tanggal 20 Maret 2019 kepada 10 orang Wanita Usia Subur 
(WUS) Di Wilayah Kerja Puskesmas Pal III didapatkan bahwa 7 orang wanita usia subur tidak pernah melakukan pemeriksaan IVA, hasil wawancara mengenai alasan mereka tidak melakukan pemeriksaan IVA yaitu karena malu, tidak melakukan karena sibuk bekerja sehingga tidak memiliki waktu untuk melakukan pemeriksaan, tidak membutuhkan karena tidak ada keluhan dan tidak ada masalah pada daerah kewanitaannya. Dari 10 ibu yang dilakukan wawancara, 2 diantaranya mengatakan belum pernah mendapatkan informasi tentang kanker serviks dan pemeriksaan IVA, 3 diantaranya mengatakan belum pernah mendapatkan penyuluhan tentang kanker serviks dan pemeriksaan IVA namun mereka mengetahui tentang kanker serviks dan pemeriksaan dari televisi dan informasi dari kader serta cerita dari teman, 5 diantaranya mengatakan sudah pernah mendapatkan penyuluhan tentang kanker serviks dan pemeriksaan IVA.

Berdasarkan uraian latar belakang di atas peneliti ingin meneliti "Pengaruh Penyuluhan Kesehatan Tentang Deteksi Dini Kanker Serviks Terhadap Motivasi Wanita Usia Subur Dalam Melakukan Pemeriksaan Inspeksi Visual Asam Asetat (IVA) Di Wilayah Kerja Puskesmas Pal III Pontianak tahun 2019".

\section{Metode}

Desain penelitian yaitu quasi experimental design dengan rancangan one group pretest design. Populasi penelitian ini sebanyak 1.683 WUS sampel sebanyak 44 orang di tambah 10 $\%$ menjadi 48 responden. Teknik sampling menggunakan Purposive Sampling. Teknik analisis yang di gunakan adalah Uji Wilcoxon Mart Pairs Test.

\section{Hasil dan Pembahasan}

Tabel 1. Distribusi Frekuensi Berdasarkan Kategori Pengetahuan Sebelum dan Sesudah Penyuluhan di Wilayah Puskesmas Pal III

\begin{tabular}{lcccc}
\hline \multirow{2}{*}{\begin{tabular}{c} 
Pengetahuan \\
\cline { 2 - 5 }
\end{tabular}} & $\begin{array}{c}\text { Jumlah } \\
\text { Responden }\end{array}$ & $\begin{array}{c}\text { Presentasi Jumlah } \\
\text { Responden (\%) }\end{array}$ & $\begin{array}{c}\text { Jumlah } \\
\text { Responden }\end{array}$ & $\begin{array}{c}\text { Presentasi } \\
\text { Jumlah } \\
\text { Responden (\%) }\end{array}$ \\
\hline Baik & 0 & 0 & 48 & 100.0 \\
Cukup & 16 & 33.3 & 0 & 0 \\
Kurang & 32 & 66.7 & 0 & 0 \\
\hline \multicolumn{2}{c}{ Berdasarkan tabel 1 di dapatkan hasil } & kurang dan didapatkan hasil pengetahuan \\
pengetahuan wanita usia subur sebelum di & wanita usia subur sesudah di lakukan & senulah penyluhan \\
lakukan penyuluhan bahwa sebagian besar & penyuluhan bahwa seluruh responden yaitu \\
reponden yaitu sebanyak 32 orang dengan & sebanyak 48 orang dengan presentase 100\% \\
presentase 66,7\% yang berpengetahuan & yang berpengetahuan baik.
\end{tabular}


Tabel 2 Distribusi Frekuensi Responden Berdasarkan Kategori Motivasi Sebelum dan Sesudah Penyuluhan di Wilayah Kerja Puskesmas Pal III

\begin{tabular}{lcccc}
\hline Motivasi & \multicolumn{2}{c}{ Motivasi Sebelum } & \multicolumn{2}{c}{ Motivasi Sesudah } \\
\cline { 2 - 5 } & $\begin{array}{c}\text { Jumlah } \\
\text { Responden }\end{array}$ & $\begin{array}{c}\text { Persentase } \\
\text { Jumlah } \\
\text { Responden (\%) }\end{array}$ & $\begin{array}{c}\text { Jumlah } \\
\text { Responden }\end{array}$ & $\begin{array}{c}\text { Persentase } \\
\text { Jumlah } \\
\text { Responden (\%) }\end{array}$ \\
\hline Tinggi & 25 & 47,9 & 34 & 70,2 \\
Rendah & 23 & 52,1 & 14 & 29,2 \\
\hline
\end{tabular}

Berdasarkan tabel 2 di dapatkan hasil motivasi wanita usia subur sebelum di lakukan penyuluhan bahwa sebagian dari responden yaitu sebanyak 23 orang dengan presentase $52,1 \%$ yang memiliki motivasi rendah. Dan Hasil penelitian ini menunjukan bahwa pengetahuan wanita usia subur sebelum di lakukan penyuluhan masih kurang hal ini di sebabkan karena kurangnya informasi yang di terima oleh responden sehingga pengetahuan yang mereka miliki terbatas, ada pula beberapa responden yg mengatakan belum pernah mendengar atau melihat informasi baik dari tenaga kesehatan maupun dari media seperti televisi sehingga tidak mengerti apa itu IVA dan tidak mengerti manfaat dari pemeriksaan IVA itu sendiri.

Hasil penelitian ini sejalan dengan pernyataan Notoatmodjo (2010), pengetahuan adalah hasil penginderaan manusia, atau hasil tahu seseorang terhadap objek melalui indera yang dimilikinya (mata, hidung, telinga, dan sebagainya). Dengan sendirinya, pada waktu penginderaan sampai menghasilkan pengetahuan tersebut sangat dipengaruhi oleh intensitas perhatian dan persepsi terhadap objek. Sebagian besar pengetahuan seseorang dapatkan hasil motivasi wanita usia subur sesudah di lakukan penyuluhan bahwa hampir Sebagian besar dari responden yaitu sebanyak 34 orang dengan presentase $70,2 \%$ yang memiliki motivasi tinggi.

diperoleh melalui indera pendengaran (telinga), dan indera penglihatan (mata).

Pengetahuan itu sendiri dipengaruhi oleh faktor pendidikan formal. Pengetahuan sangat erat hubungannya dengan pendidikan, dimana diharapkan bahwa dengan pendidikan yang tinggi maka orang tersebut akan semakin luas pula pengetahuannya. Akan tetapi perlu ditekankan, bukan berarti seseorang yang berpendidikan rendah mutlak berpengetahuan rendah pula. Pengetahuan seseorang tentang suatu objek mengandung dua aspek, yaitu aspek positif dan negatif. Kedua aspek ini yang akan menentukan sikap seseorang semakin banyak aspek positif dan objek yang diketahui, maka akan menimbulkan sikap makin positif terhadap objek tertentu (Dewi \& Wawan, 2010).

Pengetahuan yang di maksud dalam penelitian ini adalah penelitian sebelum penyuluhan dan penelitian sesudah penyuluhan. Pengetahuan sebelum penyuluhan tentang deteksi dini kanker 
serviks dengan metode IVA dinilai berdasarkan kemampuan menjawab dengan benar pernyataan pada kuesioner sebelum penyuluhan. Sedangkan pengetahuan sesudah penyuluhan tentang deteksi dini kanker serviks dengan metode IVA di nilai berdasarkan kemampuan menjawab dengan benar pertanyaan pada kuisioner setelah penyuluhan (Listyowati, 2012).

Berdasarkan tabel 1 Hasil penelitian menunjukan pengetahuan wanita usia subur setelah diberikan penyuluhan kesehatan tentang deteksi dini kanker serviks dengan metode IVA di Wilayah Kerja Puskesmas Pal $11 l$ yaitu seluruh responden atau sebanyak 48 orang dengan presentse (100\%) memiliki kategori berpengetahuan baik, Hal tersebut menunjukan bahwa penyuluhan kesehatan memiliki pengaruh yang besar terhadap pengetahuan wanita usia subur dalam melakukan pemeriksaan IVA.Pengetahuan sesudah di lakukan nya penyuluhan lebih baik di bandingkan pengetahuan sebelum di lakukannya penyuluhan, hal ini bisa terjadi di karenakan responden mendapatkan penyuluhan dengan bantuan media leaflet. Di ketahui pada saat responden menjawab pertanyaan dari peneliti. Mayoritas responden sebelumnya banyak menjawab salah dari beberapa pertanyaan dari peneliti, akan tetapi setelah di berikan penyuluhan dengan media leaflet mayoritas responden menjawab benar.

Peningkatan ini di karenakan paparan informasi yang di peroleh dari media leaflet. Informasi atau pesan penyuluhan yang di sampaikan dengan menggunakan media atau alat bantu pendidikan ini membantu pendidik dalam menyampaikan pesan tersebut agar terlihat menarik perhatian pada sasaran pendidikan. Informasi yang di berikan oleh media leaflet ini kerena informasi dapat langsung di baca dan dapat di pahami, pada dasarnya isi dari media leaflet ini berupa gambar dan tulisan sehingga terlihat lebih menarik bagi sasaran pendidikan agar mempermudah sasaran pendidikan dan si penerima informasi (Notoatmodjo, 2003).

Pengetahuan seseorang biasanya diperoleh dari pengalaman yang berasal dari berbagai macam sumber, misalnya media massa, media elektronik, buku petunjuk, petugas kesehatan, media poster, kerabat dekat dan sebagainya. Pengetahuan ini dapat membantu keyakinan tertentu sehingga seseorang berprilaku sesuai keyakinan tersebut (Afriyanti, 2011).

Berdasarkan tabel 2 hasil penelitian menunjukan bahwa motivasi wanita usia subur melakukan pemeriksaan IVA sebelum diberikan penyuluhan kesehatan IVA di Wilayah Kerja Puskesmas Pal 111 yaitu 23 orang $(52,1 \%)$ memiliki kategori motivasi rendah. Motivasi merupakan dorongan yang terdapat dalam diri seseorang untuk berusaha mengadakan perubahan tingkah laku yang lebih baik dalam memenuhi kebutuhannya. Motivasi terjadi apabila seseorang mempunyai keinginan dan kemauan untuk melakukan suatu kegiatan atau tindakan dalam langkah mencapai suatu tujuan tertentu (Mubarak, 2007). 
Volume 10 Nomor 1 Tahun 2020

Motivasi rendah WUS sebelum dilakukan penyuluhan kesehatan IVA di pengaruhi oleh beberapa faktor antara lain, kurangnya kesadaran responden akan pentingnya pemeriksaan IVA, responden menganggap dirinya sehat sehingga tidak perlu melakukan pemeriksaan IVA dan pemeriksaan IVA test adalah pemeriksaan yang memerlukan biaya.

Selain itu motivasi responden yang sangat rendah dapat dipengaruhi pula oleh informasi yang pernah diperoleh oleh responden, sebagai responden yang memiliki motivasi yang rendah belum pernah mendapatkan informasi tentang deteksi dini kanker serviks dengan metode IVA, serta terbatasnya akses informasi seperti dari internet, media cetak, media elektronik maupun media-media lainnya serta sosialisasi dari tenaga kesehatan. Hal ini diperkuat oleh pernyataan Widiatun (2005). Bahwa salah satu faktor yang mempengaruhi motivasi dalam diri seseorang adalah media atau informasi yang pernah ia dapatkan.

Saat dilakukan penelitian masih banyak responden yang belum mengetahui tentang Deteksi dini kanker serviks dengan metode IVA. Banyaknya responden yang belum mengetahui pemeriksaan IVA menunjukan behwa kurangnya akses informasi tentang IVA di wilayah tersebut, Informasi maupun media cetak dan elektronik internet serta kurangnya sosialisasi dari tenaga kesehatan (Ifada, 2010).

Kurangnya informasi yang didapat Wanita Usia Subur dapat menyebabkan rendahnya motivasi Wanita Usia Subur sehingga ibu tidak mengetahui dan tidak ada motivasi dalam dirinya untuk melakukan pemeriksaan IVA. Ada beberapa responden menganggap pemeriksaan IVA adalah pemeriksaan yang menakutkan dan membutuhkan biaya, dan responden beranggapan mereka merasa sehat sehingga tidak perlu untuk melakukan pemeriksaan IVA. Dari sebagian opini responden yang mengatakan pemeriksaan IVA ialah pemeriksaan yang menakutkan dan ibu merasa sehat menyebabkan responden memiliki motivasi rendah karena opini yang didapat tentang pemeriksaan IVA. Hal ini disebabkan karena kurangnya informasi dan penyuluhan kesehatan yang diberikan oleh tenaga kesehatan.

Hal ini sejalan dengan penelitian yang dilakukan oleh Hartati dkk (2014) bahwa tingkat motivasi Wanita Usia Subur melakukan pemeriksaan IVA katagori tinggi sebanyak 11 orang $(22,9 \%)$ dan katagori rendah sebanyak 37 orang $(77,1 \%)$ wanita usia subur yang belum memperoleh penyuluhan kesehatan mengenai IVA test menyebebkan WUS masih memiliki motivasi rendah untuk melakukan IVA test tersebut.

Hasil penelitian menunjukan motivasi wanita usia subur melakukan pemeriksaan IVA setelah diberikan penyuluhan kesehatan tentang deteksi dini kanker serviks dengan metode IVA di Wilayah Kerja Puskesmas Pal 111 Berdasarkan tabel 2 yaitu 34 orang $(70,2 \%)$ memiliki katagori motivasi tinggi dan sebanyak 14 orang $(29,2 \%)$ memiliki kategori 
motivasi rendah. Dilihat dari adanya peningkatan dari jumlah sebelumnya menunjukan bahwa penyuluhan kesehatan tentang deteksi dini kanker serviks dengan metode IVA memiliki pengaruh yang besar terhadap motivasi wanita usia subur dalam melakukan pemeriksaan IVA.

Berdasarkan ungkapan dari responden yang memiliki motivasi tinggi mengatakan bahwa motivasi yang mereka miliki dipengaruhi oleh media informasi yang mudah diterima, dipahami, dan menarik sehingga responden tidak merasa bosan dan merasa senang dalam mengikuti penyuluhan kesehatan tentang deteksi dini kanker serviks dengan metode IVA. Menurut Notoatmojo (2007) metode penyuluhan kesehatan juga dapat dipengaruhi oleh keberhasilan yang berdampak pada adanya pengaruh dari pemberian penyuluhan kesehatan. Metode pembelajaran dalam penyuluhan kesehatan dipilih berdasarkan tujuan penyuluhan kesehatan, kemampuan tenaga kesehatan sebagai pengajar, kemampuan induvidu, kelompok masyarakat, besarnya kelompok waktu pelaksanaan penyuluhan kesehatan dan ketersediaannya fasilitas pendukung.

Teori motivasi Mc Clelland dalam Notoatmodjo (2009) bahwa motif primer secara alamiah akan timbul pada individu, sedangkan motif sekunder merupakan motif yang timbul pada diri individu akibat interaksi dengan orang lain. Artinya, penyuluhan kesehatan tentang deteksi dini kanker serviks dengan metode IVA merupakan motif sekunder yang timbul dari wanita akibat interaksi dengan orang lain yang memberikan pemahaman dan keyakinan bahwa IVA bermanfaat bagi kesehatan dan dapat mencegah kenker serviks. Penyuluhan tentang deteksi dini dengan metode IVA yang diperoleh wanita usia subur akan meningkatkan pola pikir atau pendidikan WUS mengenai pemeriksaan IVA, karena seseorang yang berpendidikan tinggi akan memberikan respon yang lebih rasional terhadap informasi yang datang, dan akan berfikir sejauh mana keuntungan yang mungkin akan mereka peroleh dari gagasan tersebut (Notoadmodjo, 2007).

Walaupun sudah diberikan penyuluhan kesehatan masih ada 14 responden yang masih memiliki motivasi rendah, hal ini disebabkan responden merasa sehat sehingga tidak mau melakukan pemeriksaan IVA. Selain itu hasil observasi bahwa motivasi responden rendah setelah diberikan penyuluhan kesehatan disebabkan responden tidak memperhatikan penyuluhan kesehatan yang sedang berlangsung sehingga dalam penerimaan dan penyerap informasi kurang fokus dan maksimal dari informasi tentang penyuluhan kesehatan deteksi dini kanker serviks yang telah disampaikan. Hal ini sesuai dengan pendapat Notoatmodjo (2007) bahwa ada beberapa faktor yang dapat mempengaruhi keberhasilan dari suatu penyuluhan kesehatan antaranya faktor penyuluhan, faktor sarana, dan faktor proses dalam penyuluhan. Hal ini sejalan dengan penelitian yang dilakukan oleh Rais (2012) yang menyebutkan bahwa petugas kesehatan merupakan salah satu 
faktor pendorong individu untuk berprilaku, karena petugas kesehatan tersebut ahli dibidangnya sehingga dijadikan tempat bertanya dan memberikan informasi yang akurat. Penyampaian informasi memberikan kontribusi yang positif terhadap kesehatan yaitu deteksi dini kanker serviks dengan menggunakan metode IVA.

Pemberian penyuluhan kesehatan terutama dengan metode ceramah dapat meningkatkan kesadaran ibu-ibu akan pemeriksaan IVA dan dapat meningkatkan motivasi dan perilaku kesehatan untuk masyarakat secara keseluruhan. Hal ini sejalan dengan penelitian yang dilakukan oleh AlShaikh dkk (2007) menyebutkan bahwa terdapat peningkatan pengetahuan yang sikgnifikan setelah dilakukan penyuluhan kesehatan dengan nilai $(\mathrm{p}=<0,005)$ yang artinya bahwa program penyuluhan kesehatan dapat meningkatkan pengetahuan terhadap pencegahan skrining kanker.

Tabel 3. Analisa Bivariat

\begin{tabular}{rcccc}
\hline Variabel & N & Mean Rank & Z & p-value \\
\hline Motivasi_sebelum & 48 & 2.00 & $-5.627^{\mathrm{a}}$ &, 000 \\
Motivasi_sesudah & 41,98 & \\
\hline
\end{tabular}

Hasil analisa pada tabel 3 ini menunjukan bahwa terdapat pengaruh pemberian penyuluhan kesehatan tentang deteksi dini kanker serviks dengan metode IVA terhadap wanita usia subur melakukan pemeriksaan IVA di Wilayah Kerja Puskesmas Pal lll dengan nilai p value 0,000. Terlihat bahwa $\mathrm{p}$ value $0,000<(0,05)$, ini menunjukan ada pengaruh yang signifikan tingkat motivasi wanita usia subur sebelum dan sesudah diberikan penyuluhan kesehatan tentang IVA di Wilayah Kerja Puskesmas Pal III.

Hasil penelitian ini sejalan dengan penelitian yang dilakukan oleh Ningrum dan Fajarsari (2012) tingkat penyuluhan berpengaruh terhadap motivasi ibu mengikuti deteksi dini kanker serviks melalui metode inspeksi Visual asam asetat di Kabupaten Banyumas ( $\mathrm{p}$ value $=0,001)$. Penelitian
Sukamti dkk (2003) yang menyatakan bahwa terdapat pengaruh penyuluhan kesehatan terhadap motivasi deteksi dini kanker serviks melalui inspeksi Visual asam asetat (IVA) (p value<0,005). Penelitian Nasehah dan Loma (2013) bahwa penyuluhan berhubungan dengan pelaksanaan deteksi dini kanker serviks melalui IVA ( $\mathrm{p}$ value $=0,000$ ), dimana penyuluhan akan menumbuhkan motivasi wanita usia subuh untuk melakukan pemeriksaan IVA.

Kurangnya motivasi WUS melakukan pemeriksaan IVA sebelum dilakukan penyuluhan kesehatan disebabkan sebagian besar WUS belum pernah mendapatkan penyuluhan kesehatan tentang IVA dari tenaga kesehatan maupun informasi lainnya. Sehingga kurangnya pengetahuan ini dapat berdampak pada kurangnya motivasi WUS untuk melakukan pemeriksaan IVA. Selain 
itu, kurannya kesadaran WUS akan pentingnya pemeriksaan IVA juga berpengaruh pada kurangnya motivasi WUS. Hal ini sejalan dengan penelitian yang dilakukan oleh Abiodun dkk (2014) yang menyebutkan bahwa intervensi penyuluhan kesehatan yang diberikan dapat meningkatkan akan kesadaran kanker serviks dan skrining sampai $100 \%(\mathrm{p}=<0,0001)$. Alasan utama wanita tidak melakukan skrining kanker serviks adalah kurangnya kesadaran akan pentingnya melakukan skrining kanker serviks.

Penyuluhan kesehatan merupakan proses perubahan yang bertujuan untuk mengubah individu, kelompok dan masyarakat menuju hal positif secara terencana melalui proses belajar. Perubahan tersebut mencakup pengetahuan, sikap dan kerterampilan. Penyuluhan kesehatan secara langsung akan melibatkan proses pendengaran, pengelihatan dan ingatan yang akan menimbulkan pengetahuan baru (Machfoed, 2008).

Menurut Notoatmodjo

(2007), penyuluhan kesehatan mempunyai kelebihan yaitu penyampaian materi dapat sekaligus dalam jumlah sasaran yang banyak sehingga penggunaan waktu lebih efisien. Faktor-faktor yang mempengaruhi penyuluhan kesehatan yaitu faktor predisposisi meliputi adat istiadat, tingkat penyuluhan, tingkat sosial ekonomi, faktor pemukiman meliputi ketersediaan sarana dan prasarana dan faktor penguat yang berasal dari tokoh masyarakat, tokoh agama termasuk petugas kesehatan. Telah dilakukan pengendalian faktor yang mempengaruhi penyuluhan kesehatan pada penelitian ini yaitu tingkat penyuluhan, ketersediaan sarana dan prasarana serta faktor penguat seperti tokoh masyarakat dan petugas kesehatan.

Penyuluhan kesehatan yang dilakukan pada penelitian ini menggunakan metode ceramah dengan mengunakan media leaflet. Metode ceramah mempunyai beberapa kelebihan jika dibandingkan dengan metode yang lainnya yaitu metode sederhana yang efektif dalam penyampaian informasi untuk sasaran yang berpendidikan tinggi maupun rendah dan dapat dipakai pada kelompok yang besar (Notoatmodjo, 2006). Media leaflet adalah sebuah media yang berbentuk kertas berisikan informasi pengetahuan berupa tulisan dan gambar. Kelebihan media leaflet ini adalah kata-kata yang bersetruktur sederhana namun mudah dimengerti dan dipahami, selain itu media leaflet ringan dan mudah dibawa (Notoatmodjo, 2007).

Penyuluhan kesehatan tentang deteksi dini kanker serviks dengan metode IVA kepada WUS akan memberikan banyak informasi tentang kesehatan termasuk informasi mengenai bahaya kanker serviks dan manfaat melakukan pemeriksaan IVA, meningkatkan motivasi WUS untuk melakukan pemeriksaan IVA (Hartati dkk, 2014). Hal ini sesuai teori yang menyatakan bahwa penyuluhan kesehatan secara kesinambungan dibutuhkan oleh masyarakat untuk mendapatkan pengetahuan sehingga membutuhkan minat dan motivasi untuk 
melakukan deteksi dini dengan melakukan pemeriksaan (Sukamti dkk, 2013).

Dengan adanya pengetahuan tersebut sehingga menimbulkan pemahaman terhadapat pemeriksaan IVA. Pemahaman yang sudah ada pada diri WUS maka menumbuhkan suatu kesadaran untuk terhindar dari penyakit kanker serviks. Dengan harapan-harapan tersebut responden menerapkan perubahan tindakan pada diri sendiri untuk mendapatkan keinginan yang ingin dicapai dengan diawali dengan perubahan motivasi pada diri WUS sesudah diberikan penyuluhan kesehatan.

Selain itu, salah satu faktor yang dapat mempengaruhi tingkat motivasi seseorang adalah penyuluhan, hal ini diungkap oleh Ferliana (2011), semakin tinggi pendidikan seseorang menjadi seseorang akan memiliki pengetahuan yang luas dan pola pikirnya terbangun dengan baik. Pendidikan merupakan salah satu faktor penting yang mendorong seseorang untuk lebih peduli dan termotivasi untuk meningkatkan derajat kesehatan dirinya termasuk dalam hal melakukan pemeriksaan IVA sebagai salah satu metode deteksi dini kanker serviks.

Hal ini diperkuat oleh pernyataan Susilo (2010) bahwa penyuluhan kesehatan dan promosi kesehatan adalah bentuk intervensi atau upaya yang ditunjukan kepada perilaku, agar perilaku tersebut konduksif untuk kesehatan. Dengan kata lain penyuluhan pengupayakan agar perilaku individu, kelompok dan masyarakat mempunyai pengaruh positif terhadap pemeliharaan dan meningkatkan kesehatan penyuluhan kesehatan memiliki efek positif terhadap kesadaran kesehatan dan secara langsung berimbas pada perilaku kesehatan.

Hasil penelitian ini sejalan dengan penelitian yang telah dilakukan Chinia, dkk (2013) yang menyatakan bahwa intervensi penyuluhan kesehatan pada perempuan karena hampir sembilan dari sepuluh wanita menjalani pap-test selama enam periode setelah akhir progam penyuluhan kesehatan. Penelitian lain menyebutkan bahwa penyuluhan kesehatan mempengaruhi motivasi yaitu penelitian yang dilakukan oleh Ekawati (2012). Hasil uji stastistik menunjukan nilai siknifikan jika $\mathrm{p}=0,000$ $<(0,05)$ Maka terdapat pengaruh pemberian penyuluhan kesehatan dengan motivasi.

Motivasi yang rendah dapat dipengaruhi oleh pengetahuan tentang pentingnya melakukan pemeriksaan IVA yang kurang dan informasi yang pernah diperoleh, responden yang memiliki motivasi rendah belum pernah mendapatkan informasi tentang deteksi dini kanker serviks serta terbatasnya akses informasi dari internet, media cetak, media elektronik, ataupun media-media lainnya serta sosialisasi dari tenaga kesehatan. Hal ini diperkuat oleh pernyataan Widayatun (2013) bahwa salah satu yang mempengaruhi motivasi dalam diri seseorang adalah informasi yang pernah didapat.

Selain itu motivasi juga dapat dipengaruhi oleh dukungan keluarga, menurut teori Lawrence Green, dukungan keluarga dapat menjadi faktor penguat (reinforcing 
factor) seseorang melakukan pemeriksaan IVA. Dukungan keluarga merupakan dukungan bentuk dukungan sosial terdekat yang berlangsung sepanjang masa di kehidupan seseorang. Dukungan keluarga adalah bentuk dukungan sosial sebagai respon yang dapat dirasakan bermanfaat oleh anggota keluarga. Oleh karena itu, keluarga yang mendukung anggota keluarganya melakukan pemeriksaan IVA dapat menjadi pendorong bagi seseorang untuk berpartisipasi dalam pemeriksaan IVA. Minat dan dukungan adalah pertukaran sumber daya diantara sekurang-kurangnya dua individu dengan maksud untuk meningkatkan kesejahteraan sipenerima.

\section{Kesimpulan}

Setelah dilakukan penelitian terhadap 48 responden dan berdasarkan hasil pengumpulan data yang diperoleh di Puskesmas Pal III Pontianak Tahun 2019, dapat disimpulkan bahwa ada pengaruh penyuluhan kesehatan tentang deteksi dini kanker serviks terhadap motivasi WUS dalam melakukan pemeriksaan IVA di Wilayah Kerja Puskesmas Pal III, dengan $P$ value $=$ 0,00 $(<0,05)$, maka Ho di tolak dan Ha di terima. Diharapkan kepada petugas kesehatan untuk terus memberikan informasi tentang deteksi dini kanker serviks dengan metode IVA.

\section{Daftar Pustaka}

Afriyanti. 2011.Pendidikan Dan Perilaku Kesehatan Untuk Keperawatan. https://books.google.co.id/books diakses pada tanggal 10 april 2019 pukul 21.00 WIB.

Aqilasmart. 2010. Kanker Organ Reproduksi. Yogyakarta: A' Plus Books

Arikunto, S. 2010. Prosedur Penelitian suatu Pendekatan Praktek. Jakarta: Reneka Cipta

Bukirwa Agnes dkk. (2015). Motivations And Barriers To Cervical Cancer Screening Among HIV Infected Women In HIV Care: A Qualitative Study. Bukirwa et al. BMC Women's Health (diakses pada tanggal 25 Maret 2019 pukul 17.00 WIB)

Chinia at al.2013. Effectivenness Of Health Education Programme: Level Of Knowladge About Prevention Of Cervical Cancer Among Saudi Famele Health Care Students. Vol 67, No.4, April 2017 (diakses pada tanggal 25 Maret 2019 pukul 15.00 WIB)

Data Puskesmas Pal III. 2019. Laporan Pemeriksaan IVA Test. Puskesmas Pal III

Delia, Wijaya. 2010. Pembunuh Ganas itu Kanker Serviks. Yogyakarta: Niaga Swadaya

Depkes RI. 2007. Buku Saku Pencegahan Kanker. Jakarta

2009. Buku Saku Pencegahan Kanker Leher Rahim \& Kanker Payudara. Jakarta

Dinas Kesehatan Provinsi Kalimantan Barat. 2018. Dinas Kesehatan Provinsi Kalimantan Barat Tahun 2018. Kalbar: Profil Dinkes

Ekasari, F. M. 2009. Keperawatan Komunitas. Jakarta: Trans Info Medika

Ekawati, 2012. Pengaruh penyuluhan kesehatan tentang kontraseksi pria terhadap motivasi pria menjadi aseptor KB. (diakses pada tanggal 15 Mei 2019 pukul : 20.15 WIB) 
Emilia O, dkk. 2010. Bebas Ancaan Kanker Serviks. Yogyakarta: Pressindo

Hamzah, B. Uno. 2012. Teori Motivasi dan Pengaruhnya. Jakarta: PT Bumi Persada

Indrawati, M. 2009. Bahaya Kanker Bagi Wanita dan Pria. Jakarta: Buku Pendidikan Untuk kehidupan

Kemenkes RI. 2004. Data Informasi Kesehatan 2014.Jakarta : Kemenkes RI

Kumalasari, Intan. Andhayantoro, Iwan. 2012. Kesehatan Reproduksi untuk Mahasiswa Kebidanan dan keperawatan. Jakarta: Salemba Medika.

Liska. 2016. gambaran motivasi wanita usia subur untuk melakukan tes IVA di desa Canggal : Kec. Candirito Kab. Temenggung : diakses tanggal 28 Maret 2019 pukul 15.00 WIB.

Mahchfoed I. 2008. Pendidiikan kesehatan bagian dari promosi kesehatan. Yogyakarta: Fitramaya

Marmi. 2013. Kesehatan Reproduksi. Yogyakarta: Pustaka Pelajar

Notoatmodjo. 2007. Pengantar pendidikan dan Perilaku Kesehatan. Jakarta: Rineka Cipta

2010. Pengantar pendidikan dan Perilaku Kesehatan. Jakarta: Rineka Cipta

2012. Promosi kesehatan untuk

kebidanan. Jakarta: Rineka Cipta

Nugroho dan Utama, Indra. 2014. Kesehatan Wanita, Gender dan Permasalahanya. Yogyakarta: Nuha Medika

Nurus, H. 2010. Faktor-Faktor yang Berhubungan Dengan Motivasi wanita Usia Subur yang melakukan Pemeriksaan IVA Dalam Upaya deteksi Dini Kanker Serviks. Jurnal Penelitian. Surabaya: Fakultas Kedokteran Program Studi Kebidanan, Universitas
Airlangga. (diakses pada tanggal 23 Maret 2019 pukul 22.30 WIB)

Nursalam. 2008. Konsep \& Penerapan Metodologi Penelitian Ilmu Keperawatan: Pedoman Skripsi, Tesis dan Instrumen Penelitian. Jakarta: Salemba Medika.

Pudiastuti, D. 2011. Buku Ajar Kebidanan Komunitas dan Aplikasi dilengkapi Contoh Askeb. Yogyakarta: Nuha Medika.

Profil Dinas Kesehatan Kota Pontianak. 2017. Data informasi Kesehatan 2017.Kota Pontianak : Kalimantan Barat

Rachmadahniar. 2013. Organisasi dan Motivasi: Dasar Peningkatan Produktivitas. Jakarta: Bumi Aksara

Rahayu, leni.2017. Hubungan Antara Pengetahuan Dan Sikap Dengan Upaya Deteksi Dini Kanker Serviks Dengan Metode IVA Di Puskesmas Alianyang. Akademi Kebidanan Panca Bhakti Pontianak (Tidak di publikasikan).

Rasjidi, Imam. 2010. Panduan Penatalaksanaan kanker Ginekologi. Jakarta : EGC.

2012. Panduan Penatalaksanaan kanker Ginekologi. Jakarta : EGC.

Riyanto, Agus. 2009. Pengolahan dan Analisis Data Kesehatan Yogyakarta: Nuha Medika

Sandjaja, B \& Heriyanto, Albertus. 2006. Panduan Penelitian. Jakarta: Prestasi Pustaka raya

Septadina, indri. 2015. Upaya Pencegahan Kanker Serviks Melalui Peningkatan Pengetahuan Kesehatan Reproduksi Wanita Dan Pemeriksaan Metode IVA Jakarta: Prestasi Pustakaraya

Sopiyudin, M. 2014. Besar Sampel dan Cara Pengambilan Sampel dalam Penelitian 
Kedokteran dan Kesehatan. Jakarta: Salemba Medika

Sujarweni, Wiratna. 2014. Metodologi Penelitian Keperawatan. Yogyakarta:Penerbit Gava Media

Sugiyono. 2009. Statistika Untuk Penelitian. Bandung : IKAPI

2015. Metode Penelitian Pendidikan (pendekatan kuantitatif, kualitatif dan R\&D). Bandung: Alfabet

Taufik, M. (2007). "Prinsip -Prinsip Promosi Kesehatan Dalam Bidang Keperawatan".Jakarta : $\quad$ CV. Infomedika

Ulfah Ayu Nur Lubis dkk. 2015. Pengaruh Media Leaflet Dan Fil Terhadap Pengetahuan Tentang Kanker Serviks Dan Partisipasi Wanita Dalam Deteksi Dini Kanker Serviks Di Kampung Darek Kecamatan Padangsidempuan Selatan Tahun 201. Jurnal Ilmiah Pannmed. Vol 11 No 3 Januari-April 2017. (diakses pada tanggal 26 Maret 2019 pukul 16.00 WIB)

Wawan dan Dewi. 2011. Teori dan Pengukuran Pengetahuan, Sikap, dan Prilaku Manusia. Yogyakarta: Nuha Medika

WHO. 2009. Cancer Cerviks: Prevention and Control. (Online). (http://www.who.int/camcer/detection/ cancercerviks/en/index1.html (diakses pada tanggal 25 Maret 2019 pukul 15.30 WIB)

Zuliyanti. 2015. Kenali Kanker Sejak Dini. Yogyakarta: Penerbit Gava Media 